CLINICAL HEMORHEOLOGY, Vo1. 4, pp. 101,1984

$0271-5198 / 84 \$ 3.00+.00$ Printed in the USA.

Copyright (c) 1984 Pergamon Press Ltd. A11 rights reserved.

\title{
EDITORIAL AND PREFACE
}

This double issue $2 / 3$ of volume 4 of CLINICAL HEMORHEOLOGY comprises Part $I$ of the Proceedings of the 3rd European Conference on Clinical Haemorheology, edited by Alfred L. Copley, Holger Schmid-Schönbein and Horst Rieger. It also contains Non-Conference communications.

The Conference communications are as follows: 1 . The texts of the Fåhraeus Award Ceremony, edited by Conference Chairman Ho1ger Schmid-Schönbein. 2. Part A of Plenary Sessions "Evaluation of Haemorheological Therapy", Guest Editor H.G. Lasch and Editor S. Chien, and "Role of Haemorheology in Cardiology and Angiology", Guest Editors D. Cristal, J. Linhart, D.L. Clement and W. Schoop. 3. The Symposium "New Techniques for Haemorheology", Guest Editor M. Hanss and Editor J.A. Dormandy. 4. Conference Papers.

Since CLINICAL HEMORHEOLOGY is a journal for rapid publication, the invited Conference Papers pertaining to the Plenary Sessions and the Symposia will be published as any other communications soon after they are received at the Executive Editorial office. However, it will be indicated in future issues, as it is in this one, to which Plenary Session or Symposium the invited Conference Communication belongs.

Non-Conference Communications will be published in the same issues. This issue contains as a Non-Conference Communication the Review Article by G.V.F. Seaman and R.S. Snyder entitled "Behavior of Blood in a Low-Gravity Environment", as well as Abstracts.

Part II of the Proceedings deal with the Symposium "Rheology and Atherogenesis", held on August 24, 1983 jointly with the Fifth International Congress of Biorheology. As the Symposium does not concern clinical hemorheology, but deals with theoretical and experimental hemorheology, it is published in accordance with our editorial policy in BIORHEOLOGY Volume 21, Number 4, 1984.

Alfred L. Copley

20. April 1984 